\begin{abstract}
Aleksandar Štulhofer
Department of Sociology, Faculty of Humanities and Social Sciences, University of Zagreb
\end{abstract}

\author{
Ivan Rimac
}

Faculty of Law, University of Zagreb

\title{
DETERMINANTS OF HOMONEGATIVITY IN EUROPE
}

\author{
Corresponding author: $\quad$ Aleksandar Štulhofer, $\mathrm{PhD}$ \\ Department of Sociology \\ Faculty of Humanities and Social Sciences \\ University of Zagreb \\ I. Lucica 3, 1000 Zagreb, Croatia \\ Phone: +38516120007 \\ Fax: +38516156879 \\ E-mail: astulhof@ffzg.hr
}


Abstract: This paper analyzes macro-determinants of negative attitudes toward homosexuality in 31 European societies. Using the European Values Survey 1999/2000, carried out on national probability samples, we tested the effects of tradition, modernization, and postmodernization on homonegativity. According to the findings, social distance toward homosexual persons was predicted by the Eastern Orthodox religion, a greater degree of urbanization, economic development and immigration. Disapproval of homosexuality was found associated with economic development and urbanization, while immigration had borderline significance. Although the analyses pointed to the central role of the modernization processes in increasing social acceptance of homosexuality in European societies, persisting religious traditions and more recent immigration waves limit the effect of modernization.

Key Words: homosexuality, homonegativity, Europe, European Values Study, religion, modernization, postmodernization, immigration

\section{Introduction}

The European Parliament recently passed a resolution condemning homophobia in the European Union (European Parliament, 2006). The move was prompted, among other reasons, by a considerable difference in the treatment of homosexuality in the "old" and “new” Europe (European Commission, 2006: 42-43). After the accession round on May 1, 2004, when ten post-communist countries became the new members of the EU, new cultural divisions became a part of European reality. Clashes between the EU parliamentarians on the issues of abortion and human stem cell research (Bowley, 2005; Bilefski, 2006) and violent attacks on gay pride participants in Eastern and Southeastern Europe (Anonymous, 2001; 2007a; Levy, 2007) suggested a possibility of a European version of “culture wars”. In several Central and Eastern European countries, Poland and Romania being the most notable, but certainly not the sole examples (Anonymous, 2007b; Connely, 2007; Turcescu \& Stan, 2005; Sheeter, 2006), there is a strong political and socio-cultural opposition to gay and lesbian rights. In this oppositional bloc one invariably finds the prominent members of the national church and various, often Europhobic, right-wing political groups.

However, opposite tendencies should not be overlooked. Recently, in the two former “Eastern-bloc” countries, Slovenia (2005) and the Czech Republic (2006), a law on registered 
same-sex partnership was passed, while Hungary and Croatia adopted unregistered same-sex cohabitation (in 1996 and 2003, respectively). In the Romanian case, the negotiation process leading to EU accession provided strong pressure on local legislators, leading to the recent decriminalization of homosexuality in this country (Nachescu, 2005). Still, cross-national surveys suggest that negative attitudes toward homosexuality are more prevalent in the "new" Europe (Štulhofer \& Sandfort, 2005; Inglehart \& Welzel, 2005: 127). As recently reported, only one non-Western European country, the Czech Republic, was among the ten European countries that were most accepting of homosexuality and it occupied the last place on the list (Halman, Luijkx \& Van Zundert, 2005). In contrast, all ten least accepting countries were non-Western European countries. Opposition to gay and lesbian rights was found substantially more present in the Eastern, Southeastern and to a somewhat lesser extent Central European societies than in the Western ones (European Commission, 2006). While, for example, an overwhelming majority of Dutch citizens (82\%) supported homosexual marriage, comparable majorities of participants in Latvia, Greece and Poland objected to the idea.

Although numerous studies have analyzed socio-psychological correlates or microdeterminants of homophobia, mostly in the Western countries (Steffans \& Wagner, 2004; Adam, 1998; Davies, 2004; Herek, 1998), we are aware of only two cross-national studies that focused on macro-level correlates of homonegativity (Widmer, Treas \& Newcomb, 1998; Kelley, 2001). According to the authors of the first study, attitudes toward non-marital sex measured by the International Social Survey Program in 1994 could not be explained by a simple permissive/non-permissive society dichotomy. However, their data on disapproval of homosexual sex showed that on average the public in the old EU15 countries ${ }^{1}$ was substantially less homonegative than the public in the new members of the EU. The average

\footnotetext{
${ }^{1}$ EU15 refers to the EU composition before the May 1, 2004 accession of 10 new member states, of which eight were ex-socialist countries.
} 
proportion of participants believing that same-sex activity between two adults is "always wrong” was $54 \%$ in the first group of countries $(n=10)$ and $68 \%$ in the second group $(n=5)$. The average for the whole set of 24 countries was 59\%. Among the non-Western European countries, the Czech Republic was found the most and Hungary the least permissive (Widmer, Treas and Newcomb, 1998). The study did not analyze predictors of disapproval of homosexuality.

A more recent research study (Kelley, 2001) reported on predictors of disapproval of homosexuality in a pooled sample of 29 countries participating in the International Social Survey Project 1998-1999. Using a large sample of over 30000 participants, Kelley found all individual-level variables entered in ordinary least squares regression analysis (age, gender, education, religious beliefs, church attendance, gross domestic product /GDP/, and statesocialist past) as significant predictors. In addition, the first five predictors were also tested and confirmed separately by country (Kelley, 2001: 20). The study did not attempt to examine institutional effects - the impact of dominant cultural values and institutionalized norms and beliefs - which could be assessed only by a comparative country-level analysis.

In this paper we utilize the European Values Study 1999/2000 dataset to test the theoretically informed hypotheses about the culture-level determinants (Leung, 1989; Moors \& Wennekers, 2003; Mills et al., 2006) of negative attitudes toward homosexuals and homosexuality. We find these attitudes an important marker of social tolerance and therefore significant for the increasing culturally heterogeneous EU. The article starts with a brief outline of the three societal sources of homonegativity - tradition, modernization and postmodernization - and then proceeds to descriptive analysis and multivariate hypotheses testing.

\section{Theoretical Framework}


Beginning in the late XI century, negative attitudes toward homosexuality in Europe became the norm (Tannahill, 1996; Greenberg, 1988). In the majority of European societies ensuing increase in hostility and legal repression extended well into the XX century. As well documented, the central source of the pre-modern and early modern scorn and prosecution of homosexual, "against the nature” or sodomitic activities were the theological treatises transposed into a church doctrine (Greenberg, 1988). This process of the church-based social regulation of sexuality, marriage and reproduction (Flandrin, 1991) was not unique to the Western world. In most traditional societies, religious beliefs and norms shaped social life, particularly sexuality, reproduction and kinship (Tannahill, 1996; Reiss, 1986).

A gradual change in the social regulation of sexuality occurred with modernization. The great social transformation fueled by processes of rapid industrialization, urbanization and the development of a modern educational system replaced the traditional authority and its normative framework with the rational-legal authority based on increasingly secular rationalism (Weber, 1997). This new social regulation, as well as the inherent logic of burgeoning capitalism, proved conducive to the expansion of the culture of individualism. In the second half of the XX century, the modern transformation of social regulation of sexuality was completed by the revolution of sexual permissiveness (McLaren, 1999). Modernity, it was suggested, ended about the same time. Late modernity or postmodernization followed (Giddens, 1990; Inglehart, 1997), characterized by further expansion, even globalization, of the culture of permissiveness (Halman, 1995). In the process, freedom of sexual choices, including the non-heterosexual ones (embodied, but not exclusively, by sexual minorities), personal autonomy, and the acceptance of diversity became undisputed values of the contemporaneity (Giddens, 1992; Weeks, 1995; Schmidt, 1998).

This brief overview pointed to three major sources of social regulation of sexuality: religious tradition, the modernization processes, and the contemporary dynamics of 
postmodernization. Measuring the impact of the three dimensions in their temporal sequence forms the basis of our analysis of macro-determinants of homonegativity.

\section{Impact of Tradition}

Christianity played a major historical role in the socio-cultural development of European societies, which was recently reflected in the heated political debate over the inclusion of the Christian legacy ("Christian roots of Europe") in the European Constitution (Black, 2004). However, the impact of this religious legacy is far from uniform. Historical differences between the Protestant, Catholic and Orthodox Church added a specific component to the North-South and the West-East divide. In the European context, it has been observed that Protestant countries were less sexually restricted than the Catholic and Eastern Orthodox ones. For example, the Netherlands, UK and Sweden were the first European countries to promote family planning and school-based sex education (Francoeur \& Noonan, 2004).

The religious tradition model stipulates that homonegativity would be affected differentially by historically dominant religious denominations. It should be noted here that our approach focuses on the impact of religious values on everyday culture, including the non-religious institutions, and not on the religious individuals in national samples. Our model assumes that a religious tradition will influence both religious and non-religious individuals in a given society through its imprint on local institutions and the cultural meanings they produce.

Impact of Modernization

Modernity has a mixed record on sexual freedom. The XIX century Victorian ideology, early medicalization of sexuality and hygienic reforms imposed a new system of 
control and repression of deviant sexuality, which also included "excessive” heterosexuality (Katz, 1995). However, from the end of the century on, Western sexual morals were gradually relaxed due to secularization and decreasing social control in large urban settings. These were the consequences of the influx of liberal values generated by the expanding educational system, rising standard of life (Greenberg, 1988; D’Emilio \& Freedman, 1988), and the emerging new culture of individualism (Simmel, 1980[1903]; Giddens, 1991). In the interwar period, during the 1920s and 1930s, homosexual communities were common and occasionally socially visible in large European cities (Greenberg, 1988). In the second part of the XX century, decriminalization of homosexuality and its subsequent removal from the list of mental illnesses prompted by the emerging gay and lesbian liberation movement marked a new moral climate in the West (Greenberg, 1988; LeVay, 1996). This history is specified in the modernization model, which posits that homonegativity would be diminished by the processes of modernization - mass education, urbanization and economic growth in particular.

\section{Impact of Postmodernization}

In a series of studies, Ronald Inglehart (1990; 1997; Inglehart \& Welzel, 2005) proposed that a new global cultural shift began in the second half of the last century. With the post-industrial phase of modernity replacing the old industrial one, values of individual freedom and self-expression started replacing the earlier emphasis on economic achievement and security. The turn brought an "increasing emancipation from both religious and secularrational authority” (Inglehart, 2006:115; see also Weber, 1997) and a growing importance of quality of life and human rights. Unsurprisingly, this emerging postmaterialist worldview was found significantly associated with the acceptance of homosexuality (Inglehart, 1990) and sexual permissiveness in general (Halman, 1995; Inglehart, 1997). However, the described dynamics could be affected by immigration flows intensified by globalization (Qingwen, 
2007). Growing immigration to the Western post-industrial societies is motivated primarily by economic and security needs (OECD, 2006; UNDESA, 2006). This and the fact that a substantial proportion of immigrants originate from the non-European cultures (some of which are extremely repressive and punitive with regards to same-sex sexual activities) increases cultural heterogeneity in Western European countries.

Referring to these dual dynamics, the postmodernization model postulates that attitudes toward homosexuality would be affected by contemporary postmaterialism, as well as by the immigration flow. These two parallel processes, it is expected, would have opposite effects on homonegativity.

\section{Method}

\section{Dataset}

The European Value Study (EVS) is a large-scale, cross-national longitudinal survey initiated as a collaborative international research project in the late 1970s (www.europeanvalues.nl). In the analyses presented in this paper we use data collected in the third wave (1999/2000), when the survey was carried out in 33 European countries, including Turkey. In total, data from over 41,000 participants were collected. The size of the national samples varied from over 900 to 2000 participants.

In each participating country, the EVS was carried out on a multi-stage probabilistic sample of participants aged 18 years and older. A uniform procedure, face-to-face interviewing at the participant's home, was used for collecting data. Specific guidelines for the survey were provided by the coordinator, and the national research teams were required to provide detailed information about the translation of the standardized questionnaire, sampling procedures, fieldwork, weighting, national codes, and the inclusion of optional (countryspecific) questions. The master questionnaire used in the EVS 1999/2000 wave asked 112 
questions (332 variables). In the cases where inconsistencies in procedure were detected, the variables were excluded from the national dataset.

Response rates varied across the countries ${ }^{2}$. With the exception of Spain (25\% response rate), the response rate range was 40-95\% (Halman, 2001). The average response rate in the Western European countries was 64\% and in the Eastern European countries 67\%. In 21 out of 32 national samples, post-stratification weighting was applied to improve the accuracy of survey estimates and correct for the non-response bias (Little, 1993). The validity and comparability of national survey data were assessed by the EVS coordinating team using a number of procedures including content analysis of item wording (in national languages), outlier analysis, and construct validity assessment.

\section{Instruments}

Homonegativity was operationalized through two indicators. The indicator of the social distance toward homosexuals was the percentage of respondents who mentioned homosexuals when asked about groups of people they "would not like to have as neighbor." The second indicator, the Justification of Homosexuality Percentage Difference Index, was based on the participant's approval of homosexuality. This should be distinguished from attitudes toward homosexual individuals. By homosexuality people usually refer, both cognitively and discursively, to same-sex sexual activity, which is not surprising since partner-specific sexual activity is one of the core dimensions in defining sexual orientation. Participants were asked if homosexuality "can always be justified, never be justified or something in between.” A 10-point scale (1 = never, 10 = always) was used for recording answers. The index was computed by subtracting the percentage of participants for whom homosexuality was "always justified" from the percentage of those for whom it was "never

\footnotetext{
${ }^{2}$ Response rates for nine countries were not reported (Halman, 2001: 368).
} 
justified”. Negative scores thus represent approval of homosexuality. In methodological terms, the simplicity of both indicators tends to minimize the construct equivalence problem (Mills et al., 2006; Moors and Wennekers, 2003). The two indicators of homonegativity were highly correlated $(\mathrm{r}=.90, p<.01)$.

Historical religion was measured with three dummy variables (Catholicism, Protestantism, and Eastern Orthodoxy), of which Protestantism was assigned the reference category. Data on historical religion were taken from Melton and Baumann (2002). Education was measured as the percentage of college-educated participants in the national samples. Urbanization was operationalized as the percentage of respondents living in cities with 100,000 or more inhabitants. Economic development was assessed with the real GDP per capita (GDP per capita converted into US dollars on the basis of the purchasing power parity exchange rate) in 1999 (IMF, 2000). Following Inglehart (1997), the Index of Postmaterialism was expressed as the percentage of participants favoring postmaterialist societal goals such as “giving people more say in important government decisions” minus the percentage of participants favoring materialist goals ("maintaining order” and "fighting rising prices”). Immigration was operationalized as the percentage of immigrants in the national population (UNDESA, 2006).

\section{Results}

Table 1 provides descriptive data on homonegativity in 32 European societies. ${ }^{3}$ As expected, Scandinavian countries and the Netherlands were found the least homonegative, or the most approving societies. On the other end of the scale were Lithuania, Romania, Ukraine, Russia, and Belarus as the most homonegative societies among those surveyed in 1999. A religious dimension of the divide can hardly be overlooked: all four of the least homonegative

\footnotetext{
${ }^{3}$ As the only predominantly Muslim country in the EVS 1999/2000 dataset, Turkey was excluded from analyses.
} 
countries were predominantly Protestant, while four out of five of the least accepting countries were Eastern Orthodox.

\section{TABLE 1 ABOUT HERE}

The range of homonegativity in Europe is more evident in Figure 1. In comparison to the old EU countries (the EU-15), participants from the countries that recently joined the EU and the non-EU countries (with the exception of Iceland) were found to be more homonegative. Three clusters of countries are clearly noticeable. The first and the least homonegative cluster included the Netherlands and the Nordic countries, with the exception of Finland. The second cluster consisted of the old EU countries and the traditionally permissive Czech Republic (Widmer, Treas and Newcomb, 1998). The third and the most homonegative cluster is made up of the recent EU members and the non-EU countries. With the exception of Malta, this cluster represented Central, South-Eastern and Eastern European societies. Interestingly, two Central European countries, Slovenia and Slovakia, were positioned somewhere in-between the second and the third cluster. Both societies were characterized by a relatively low disapproval of homosexuality and a relatively high distance toward homosexuals.

\section{FIGURE 1 ABOUT HERE}

To analyze macro or societal predictors of homonegativity, hierarchical multiple regression analyses was carried out with the indicators of homonegativity as dependent variables. The regression models were built in three steps. Historical religion was entered in the first step, indicators of modernization were added in the second step, and, in the final step, 
indicators of postmodernization were entered in the model. The results are summarized in Table 2.

In the case of social distance toward homosexuals, we found evidence of a significant impact of all three hypothesized dimensions. Although Eastern Orthodoxy remained a positive predictor in all three steps, suggesting a persisting effect of tradition, adding the indicators of modernization - particularly urbanization and real GDP per capita - more than doubled the percentage of explained variance (from 34\% to 79\%) of the dependent variable. As hypothesized, the effects of modernization were negative: the higher the levels of urbanization and economic development, the lower the proportion of national population objecting to having a homosexual neighbor. Adding the indicators of postmodernization improved the predictability of social distance toward homosexuals only slightly. Of the two postmodernization indicators, only immigration was found significantly and positively associated with the dependent variable. The more prevalent immigration, the more social distance reported.

Religious tradition was not found a significant determinant of the country-level disapproval of homosexuality. ${ }^{4}$ Although initially relevant, Eastern Orthodoxy lost statistical significance after the modernization indicators were entered in the model. The latter substantially improved the predictability of the disapproval of homosexual activity. As in the case of social distance toward homosexual persons, adding the postmodernization variables resulted in a marginal increase of the percentage of explained variance. In the final step, both economic development and urbanization remained significant, while immigration - the indicator that significantly predicted social distance toward homosexuals - was found

\footnotetext{
${ }^{4}$ To explore a possible relationship between fundamentalist religious beliefs and homonegativity, we tested the association between each of the two indicators of homonegativity and a crude indicator of the acceptance of religious fundamentalism ("Politicians who do not believe in God are unfit for public office“; 1 = "agree strongly" to 5 = "disagree strongly”). The average coefficients were significant $(p<.01)$ and pointed in the expected direction. The acceptance of fundamentalist beliefs increased the likelihood of social distancing toward homosexuals $\left(\mathrm{r}_{\mathrm{pb}}=-.14\right)$ and disapproval of homosexuality $\left(\mathrm{r}_{\mathrm{s}}=-.20\right)$.
} 
bordering on statistical significance $(p<.058)$. Considering the sample size $(n=32)$, the effect of immigration should be taken into consideration.

\section{TABLE 2 ABOUT HERE}

Since 15 of the 32 surveyed countries had a state-socialist past, we also tested for possible effects of socialism (not presented here). Similar to an earlier report (Kelley, 2001), this dummy variable was found to be a significant predictor of social distance toward homosexuals, but only after GDP was omitted from the regression model. ${ }^{5}$ Serious collinearity concerns governed the removal of the socialism dummy from final analyses. Rerunning the analyses without it did not affect the significance of other independent variables.

\section{Discussion}

Confirming a recent observation from the Eurobarometer study (European Commission, 2006), our analysis revealed substantial differences in the degree of homonegativity in Europe. In comparison to the old EU member countries, homonegativity was more strongly expressed in the new EU member states. Clearly, there are a number of socio-cultural differences between the two groups of countries, some of which were recently highlighted as a major cause of concern for the future of the EU (Fuchs \& Klingemann, 2002). The old EU members are economically more developed, more politically stable, and are characterized by better functioning democratic institutions and more efficient legal systems (Mishler \& Rose, 1997; Rose-Ackerman, 2001). As recently shown, the new EU members differ significantly from the old EU members in generalized trust, involvement in civic organizations, and confidence in institutions (Rimac \& Štulhofer, 2004).

\footnotetext{
${ }^{5}$ Zero-order correlation between real GDP and socialism was -.82, indicating collinearity.
} 
Differences in homonegativity were also observed within the old EU group.

Scandinavian countries and the Netherlands were found the most accepting of homosexuality and the Mediterranean countries (Portugal, Italy, and Greece) and Ireland the least accepting. These differences reflect a tradition of sexual permissiveness, openness and tolerance in the Nordic countries (Weinberg, Lottes, \& Shower, 1995), but could have also been affected by a differential religious emphasis on sexuality issues, especially the same-sex marriage. In contrast to a more subdued approach exercised by the Protestant Church, the Roman Catholic Church pursues a vigorous and high-profile battle against the legalization of non-heterosexual marriage. Consequently, homonegativity in the Roman Catholic countries may have been strengthened by the Vatican's opposition to the changing of the marital law, as well as queer manifestations like gay pride marches.

Among the new members of the EU and the other post-communist countries, the Eastern Orthodox countries were found higher in homonegativity than the Roman Catholic. A similar finding was reported by Inglehart and Welzel (2005: 127), who used the World Values Survey database. In comparison to the Protestant and Catholic religion, we found Eastern Orthodoxy to increase the prevalence of social distance toward homosexuals, regardless of the level of modernization. Interestingly, an earlier study found the Orthodox religious heritage negatively associated with values of self-expression and attitudes toward abortion and childrearing, even after controlling for economic development and social structure (Inglehart \& Baker, 2000: 40). One possible explanation points to the demise of state-socialism and the resulting desecularization (Inglehart \& Baker, 2000; Štulhofer \& Sandfort, 2005; Borowik, 2006). If modernization and tradition are mutually restrictive, the extent and intensity of desecularization will depend on the speed and success of post-communist transition. In comparison to the post-communist Central European countries, mostly Roman Catholic, the Eastern Orthodox societies in the Eastern and South-Eastern Europe experienced a more 
socially destructive and delayed transition, both in political and socio-economic terms (UNDP, 1998; Borowik, 2006). Socio-psychological costs of transitional anomie and pauperization, according to Borowik (2006), revived Orthodoxy by reshaping it into a tool for re-building personal and collective identity in a rapidly changing social environment.

Unexpectedly, postmaterialist values did not improve empirical understanding of homonegativity. It was expected that well-documented intergenerational rise of postmaterialist values (Inglehart, 1990; 1997) would independently decrease homonegativity, as suggested by Inglehart and Welzel (2005: 40-41). However, the lack of predictive power of this global cultural shift should not be completely surprising. The rise of postmaterialistic values, as argued by Inglehart (1990; 1997), is a consequence of growing up with material security created by economic development and prosperity. Hence, the effect of postmaterialism would be subsumed by the effect of economic development ${ }^{6}$. In addition, postmodernization is commonly conceptualized not as a radical departure from but rather a (more reflexive and skeptical of authority) continuation of modernization (Giddens, 1991; Beck, Giddens, \& Lash, 1994; Inglehart, 1997).

Finally, several study limitations should be mentioned. Although response rates varied among the countries included in the EVS 1999/2000 (Halman, 2001: 368), a systematic nonresponse analysis was not attempted. However, a number of procedures were employed to minimize biases and increase precision and validity. In addition to post-stratification that was applied to reduce the risk of systematic bias, the comparability of national survey data was carefully assessed. This resulted in the removal of all the variables that were found unfit for cross-national analysis.

Another limitation is related to some of the indicators used in our study. For example, it is not clear whether the Justification of Homosexuality Percentage Difference Index

\footnotetext{
${ }^{6}$ Moderately high zero-order correlation (.70) between real GDP per capita and Index of Postmaterialism seemed to confirm Inglehart's “scarcity hypothesis” (Inglehart, 1990; 1997; Inglehart and Welzel, 2005).
} 
measures the (dis)approval of same-sex sexual activities or the (dis)approval of homosexual activities and homosexual identity. This imprecision was unavoidable since the EVS questionnaire did not define "homosexuality”. Methodological difficulties were also present in measuring participants' education. The indicator used (percentage of college educated individuals) is clearly insensitive to the quality of and the dominant values embedded in different national systems of higher education. In addition, education was not uniformly recorded. Several country reports contained nation-specific categories, which were later recoded into a standardized, one-size-fits-all scale.

\section{Conclusion and Implications}

The analysis of societal predictors of homonegativity presented in this paper demonstrated the central role of modernization processes in increasing social acceptance of homosexuality in contemporary European societies. Economic development and the process of urbanization significantly increase social tolerance and acceptance of homosexuality. Less expectedly, our findings pointed out that persisting religious tradition and immigration flows may limit the effects of modernization. The findings have ramifications for future EU enlargement and inform present debates about human rights protection, religious values and European identity (Black, 2004; Bowley, 2005; Bilefski, 2006).

The effect of immigration seems to be of particular importance. The cultural impact of immigration has recently become a topic of heated debates, primarily because of concerns over the alleged radicalization of young Muslim immigrants, which was attributed to failed integration. In a different vein, a recent Dutch proposal aimed at dealing with the increasing cultural heterogeneity that was perceived as endangering the liberal foundations of the Dutch

cultural system (Crouch, 2006), emphasized the need to address cultural tensions associated with immigration. Although initially controversial, the movie ("To the Netherlands”) that was 
made a part of the entrance examination for prospective immigrants, intended to familiarize the applicants with Dutch values (among others, the movie contained a scene of two men kissing). Our study does not only suggest that immigrant subcultures could be more sexually restrictive than the host culture, but also that the existing national curricula in Europe may not be as efficient in promoting social tolerance as is commonly believed. In addition, it would be a mistake to assume that economic development will necessarily create moral convergence and a universal respect of human rights. A more proactive approach, as recently exercised by the European Parliament (European Parliament, 2006), seems timely and much needed. 


\section{References}

Anonymous. (2001, June 30). Belgrade gay march clashes. BBC News, Retrieved July 1, 2007, from http://news.bbc.co.uk/2/hi/europe/1415789.stm

Anonymous. (2007a, June 10). Attackers stone gay rights marchers in Romania. Associated Press, Retrieved July 1, 2007, from http://www.kfsm.com/global/story.asp?s=6636785

Anonymous. (2007b, June 29). Poland rejects EU charter on homosexual rights. Catholic World News, Retrieved July 1, 2007, from http://www.europarl.europa.eu/sides/getDoc.do?pubRef=-//EP//TEXT+TA+200601

Adam, B. D. (1998). Theorizing homophobia. Sexualities, 1, 387-404.

Beck, U., Giddens, A., \& Lash, S. (1994). Reflexive modernization: Politics, tradition and aesthetics in the modern social order. Cambridge: Polity Press.

Bilefski, D. (2006, July 25). EU to finance stem cell research. International Herald Tribune, Retrieved July 1, 2007, from http://www.iht.com/articles/2006/07/25/news/union.php

Black, I. (2004, May 25). Christianity bedevils talks on EU treaty. Guardian, Retrieved July 6, 2007, from http://politics.guardian.co.uk/eu/story/0,9061,1224008,00.html

Borowik, I. (2006). Orthodoxy confronting the collapse of communism in post-Soviet countries. Social Compass, 52, 267-276.

Bowley, G. (2005, November 24). Poland and Brussels face clash of cultures. International Herald Tribune, Retrieved July 1, 2007, from http://www.iht.com/articles/2005/11/24/news/poland.php

Connely, K. (2007, March 20). Poland to ban schools from discussing homosexuality. Guardian, Retrieved July 1, 2007, from http://www.guardian.co.uk/gayrights/story/0,,2038057,00.html

Crouch, G. (2006, March 17). Dutch immigration kit offers a revealing view. New York Times, Retrieved July 18, 2007, from http://www.iht.com/articles/2006/03/16/news/dutch-5852942.php

Davies, M. (2004). Correlates of negative attitudes toward gay men: Sexism, male role norms, and male sexuality. Journal of Sex Research, 41, 259-266.

D’Emilio, J., \& Freedman, E. B. (1988). Intimate matters: A history of sexuality in America. Chicago: University of Chicago Press.

Europan Commission. (2006). Eurobarometer 66: Public opinion in the European UnionFirst results, December 2006, Retrieved July 1, 2007, from http://ec.europa.eu/public_opinion/archives/eb/eb66/eb66_highlights_en.pdf

European Parliament. (2006). European Parliament resolution condemning "homophobia", Retrieved July 1, 2007, from http://www.europarl.europa.eu/sides/getDoc.do?pubRef=-//EP//TEXT+TA+200601

Flandrin, J. L. (1991). Sex in the Western world: The development of attitudes and behaviour. Chur: Hardwood Academic.

Francoeur, R. T., \& Noonan, R. J. /Eds./ (2004). International encyclopedia of sexuality. New York: Continuum. 
Fuchs, D., \& Kligemann, H. D. (2002). Eastward enlargement of the European Union and the identity of Europe. West European Politics, 25, 19-54.

Giddens, A. (1990). The consequences of modernity. Stanford, CA: Stanford University Press.

Giddens, A. (1991). Modernity and self-identity. Cambridge: Polity Press.

Giddens, A. (1992). Transformation of intimacy. Stanford, CA: Stanford University Press.

Greenberg, D. F. (1988). The construction of homosexuality. Chicago: University of Chicago Press.

Halman, L. (1995). Is there a moral decline? International Social Science Journal, 145, 419439.

Halman, L. (2001). The European Values Study: A third wave - source book of the 1999/2000 European Values Study surveys. Tilburg: Tilburg University.

Halman, L., Luijkx, R., \& Van Zundert, M. (2005). Atlas of European values. Leiden: Brill Academic Publishers.

Herek, G. (Ed.) (1998). Stigma and sexual orientation: Understanding prejudice against lesbians, gay men, and bisexuals. Thousand Oaks, CA: Sage.

Inglehart, R. (1990). Culture shift in advanced industrial societies. Princeton, NJ: Princeton University Press.

Inglehart, R. (1997). Modernization and postmodernization. Princeton, NJ: Princeton University Press.

Inglehart, R. (2006). Mapping global values. Comparative Sociology, 5, 115-136.

Inglehart, R., \& Baker, W. (2000). Modernization, cultural change, and the persistence of traditional values. American Sociological Review, 65, 19-51.

Inglehart, R., \& Welzel, C. (2005). Modernization, cultural change, and democracy. Cambridge: Cambridge University Press.

International Monetary Fund. (2000). The world economic outlook database, Retrieved July 19, 2007, from http://www.imf.org/external/pubs/ft/weo/2000/02/data/index.htm

Katz, J. N. (1995). The invention of heterosexuality. New York: Plume.

Kelley, J. (2001). Attitudes towards homosexuality in 29 nations. Australian Social Monitor, $4,15-21$.

Levy, M. (2007, May 27). Eggs and punches at Russia gay march. BBC News, Retrieved July 1, 2007, from http://news.bbc.co.uk/2/hi/europe/6696329.stm

Leung, K. (1989). Cross-cultural differences: Individual level vs. culture-level analysis. International Journal of Psychology, 24, 703-719.

LeVay, S. (1996). The queer science: The use and abuse of research into homosexuality. Cambridge, MA: MIT Press.

Little, K. J. A. (1993). Post-stratification: A modeler's perspective. Journal of the American Statistical Association, 88, 1001-1012.

McLaren, A. (1999). Twentieth-century sexuality: A history. Oxford: Blackwell.

Melton, J. G., \& Baumann, M. (Eds.) (2002). Religions of the world, I-IV. Santa Barbara, CA: ACC-Clio. 
Mills, M., van de Bunt, G. G., \& de Bruijn, J. (2006). Comparative research: Persistent problems and promising solutions. International Sociology, 21, 619-631.

Mishler, W., \& Rose, R. (1997). Trust, distrust and skepticism: Popular evaluation of civil and political institutions in post-communist societies. Journal of Politics, 59, 418-451.

Moors, G., \& Wennekers, C. (2003). Comparing moral values in Western European countries between 1981 and 1999: A multiple group latent-class factor approach. International Journal of Comparative Sociology, 44, 155-172.

Nachescu, V. (2005). Hierarchies of difference: National identity, gay and lesbian rights, and the church in postcommunist Romania. In A. Štulhofer \& T. G. M. Sandfort (Eds.), Sexuality and gender in postcommunist Eastern Europe and Russia (pp. 57-77). New York: The Haworth Press.

Organization for Economic Cooperation and Development. (2006). OECD factbook 2006: Economic, environment, and social statistics. Paris: OECD.

Reiss, I. (1986). A sociological journey into sexuality. Journal of Marriage and the Family, 48, 233-242.

Rimac, I. \& Štulhofer, A. (2004). Socio-cultural values, economic development and political stability as correlates of trust in the European Union. In K. Ott (Ed.) Croatia accession to the European Union: Institutional challenges (pp. 301-326). Zagreb: Institute of Public Finance. /Available at: http://www.ijf.hr/eng/EU2/Rimac-stulhofer.pdf/

Rose-Ackerman, S. (2001). Trust and honesty in post-socialist societies. Kyklos, 54, 415-444.

Qingwen, X. (2007). Globalization, immigration and the welfare state: A cross-national comparison. Journal of Sociology and Social Welfare, 34, 87-106.

Schmidt, G. (1998). Sexuality and late modernity. Annual Review of Sex Research, 9, $224-$ 241.

Sheeter, L. (2006, June 16). Latvia defies EU over gay rights. BBC News, Retrieved July 1, 2007, from http://news.bbc.co.uk/2/hi/europe/5084832.stm

Simmel, G. (1980[1903]). Metropolis and mental life. In: K. Wolff (Ed.) The sociology of Georg Simmel (pp. 409-424). New York: Free Press.

Steffans, M. \& Wagner, L. (2004.) Attitudes toward lesbians, gay men, bisexual women, and bisexual men in Germany. Journal of Sex Research, 41, 137-149.

Štulhofer, A. \& Sandfort, T. G. M. (2005). Introduction. In A. Štulhofer \& T. G. M. Sandfort (Eds.), Sexuality and gender in postcommunist Eastern Europe and Russia (pp. 1-25). New York: The Haworth Press.

Tannahill, R. (1996). Sex in history. London: Abacus.

Turcescu, L., \& Stan, L. (2005). Religion, politics and sexuality in Romania. Europe-Asia Studies, 57, 291-310.

United Nations Department of Economic and Social Affairs. (2006). International migration 2006, Retrieved July 7, 2007, from http://www.un.org/esa/population/publications/2006Migration_Chart/Migration2006.p df

United Nations Development Programme. (1998). Human development under transition: Europe and CIS. New York: UN Publications. 
Weber, M. (1997). The theory of social and economic organization. New York: The Free Press.

Weeks, J. (1995). Invented moralities: Sexual values in an age of uncertainty. New York: Columbia University Press.

Weinberg, M., Lottes, I. L., \& Shower, F. M. (1995). Swedish or American heterosexual college youth: Who is more permissive? Archives of Sexual Behavior, 24, 409-437.

Widmer, E. D., Treas, J., \& Newcomb, R. (1998). Attitudes toward non-marital sex in 24 countries. Journal of Sex Research, 35, 349-358. 
Table 1 - Percentage of participants expressing negative attitudes toward homosexuality in 32 European societies (1999/2000)

\begin{tabular}{|c|c|c|}
\hline & $\begin{array}{c}\text { Indicator A } \\
\text { Would not like to have } \\
\text { homosexual neighbor }\end{array}$ & $\begin{array}{c}\text { Indicator B } \\
\text { Can homosexuality be } \\
\text { justified: “never" - } \\
\text { "always”a }\end{array}$ \\
\hline & \multicolumn{2}{|c|}{$\%$} \\
\hline France & 15.6 & 6.4 \\
\hline The United Kingdom & 24.3 & 10.4 \\
\hline Germany & 13.1 & -4.2 \\
\hline Austria & 25.4 & 2.3 \\
\hline Italy & 28.7 & 15.6 \\
\hline Spain & 16.4 & -0.5 \\
\hline Portugal & 25.2 & 40.0 \\
\hline The Netherlands & 6.2 & -40.6 \\
\hline Belgium & 17.4 & 6.9 \\
\hline Luxemburg & 18.6 & -5.9 \\
\hline Denmark & 8.1 & -21.0 \\
\hline Sweden & 6.1 & -41.9 \\
\hline Finland & 21.3 & 11.0 \\
\hline Iceland & 7.9 & -30.6 \\
\hline Northern Ireland & 35.2 & 30.7 \\
\hline Republic of Ireland & 26.9 & 23.5 \\
\hline Estonia & 46.2 & 51.1 \\
\hline Latvia & 45.5 & 75.0 \\
\hline Lithuania & 67.6 & 76.6 \\
\hline Poland & 55.2 & 53.2 \\
\hline Czech R. & 19.7 & 3.5 \\
\hline Slovakia & 44.0 & 11.9 \\
\hline Hungary $^{\mathrm{b}}$ & 1 & 86.4 \\
\hline Romania & 65.2 & 77.7 \\
\hline Bulgaria & 53.9 & 56.7 \\
\hline Croatia & 52.8 & 64.5 \\
\hline Slovenia & 44.3 & 20.7 \\
\hline Greece & 26.8 & 12.9 \\
\hline Malta & 39.6 & 58.1 \\
\hline Russia & 57.9 & 68.4 \\
\hline Ukraine & 65.7 & 68.0 \\
\hline Belarus & 63.3 & 52.5 \\
\hline
\end{tabular}

${ }^{\text {a}}$ The percentage of respondents who believe that homosexuality can never be justified minus the percentage of respondents who believe that homosexuality can always be justified.

${ }^{b}$ Hungarian data on social distance was removed from the EVS dataset due to a non-standard interviewing procedure applied. 
Table 2 - Predictors of homonegativity in Europe

\begin{tabular}{|c|c|c|c|c|c|c|}
\hline & \multicolumn{2}{|c|}{$\begin{array}{c}\text { Model I } \\
\text { Religious tradition }\end{array}$} & \multicolumn{2}{|c|}{$\begin{array}{c}\text { Model II } \\
\text { Modernization }\end{array}$} & \multicolumn{2}{|c|}{$\begin{array}{c}\text { Model III } \\
\text { Postmodernization }\end{array}$} \\
\hline & $\mathrm{A}$ & $\mathrm{B}$ & A & $\mathrm{B}$ & $\mathrm{A}$ & $\mathrm{B}$ \\
\hline & \multicolumn{6}{|c|}{$\operatorname{Beta}(t)$} \\
\hline $\begin{array}{c}\text { Traditional religion } \\
\text { Protestant (ref.) }\end{array}$ & & & & & & \\
\hline Catholic & $.31(1.82)$ & $.37(2.03)$ & $.02(.20)$ & $.09(.67)$ & $.00(.04)$ & (11 (.89) \\
\hline Orthodox & $.70(4.15)^{* *}$ & $.56(3.04)^{* *}$ & $.41(3.37)^{* *}$ & $.25(1.59)$ & $.37(3.20)^{* *}$ & $.13(.81)$ \\
\hline Education & & & $-.16(-1.56)$ & $-.17(-1.34)$ & $-.16(-1.68)$ & $-.10(-.74)$ \\
\hline Urbanization & & & $-.36(-3.39)^{* *}$ & $-.28(-2.13)^{*}$ & $-.38(-4.01)^{* *}$ & $-.26(-2.10)^{*}$ \\
\hline GDP & & & $-.62(-5.60) * *$ & $-.64(-4.52)^{* *}$ & $-.78(-6.10)^{* *}$ & $-.66(-3.87)^{* *}$ \\
\hline Postmaterialism & & & & & $-.02(-.19)$ & $-.25(-1.51)$ \\
\hline Immigration & & & & & $.27(3.11)^{* *}$ & $.23(2.00)$ \\
\hline$R^{2}$ adjusted & .34 & .20 & .79 & .64 & .84 & .70 \\
\hline
\end{tabular}

$\mathrm{A}=$ proportion of respondents who would not like to have a homosexual neighbor; $\mathrm{B}=$ the percentage of respondents who believe that homosexuality can never be justified minus the percentage of respondents who believe that homosexuality can always be justified

$* p<.05, * * p<.01$ 
Figure 1 - Negative attitudes toward homosexuality in 31 European societies

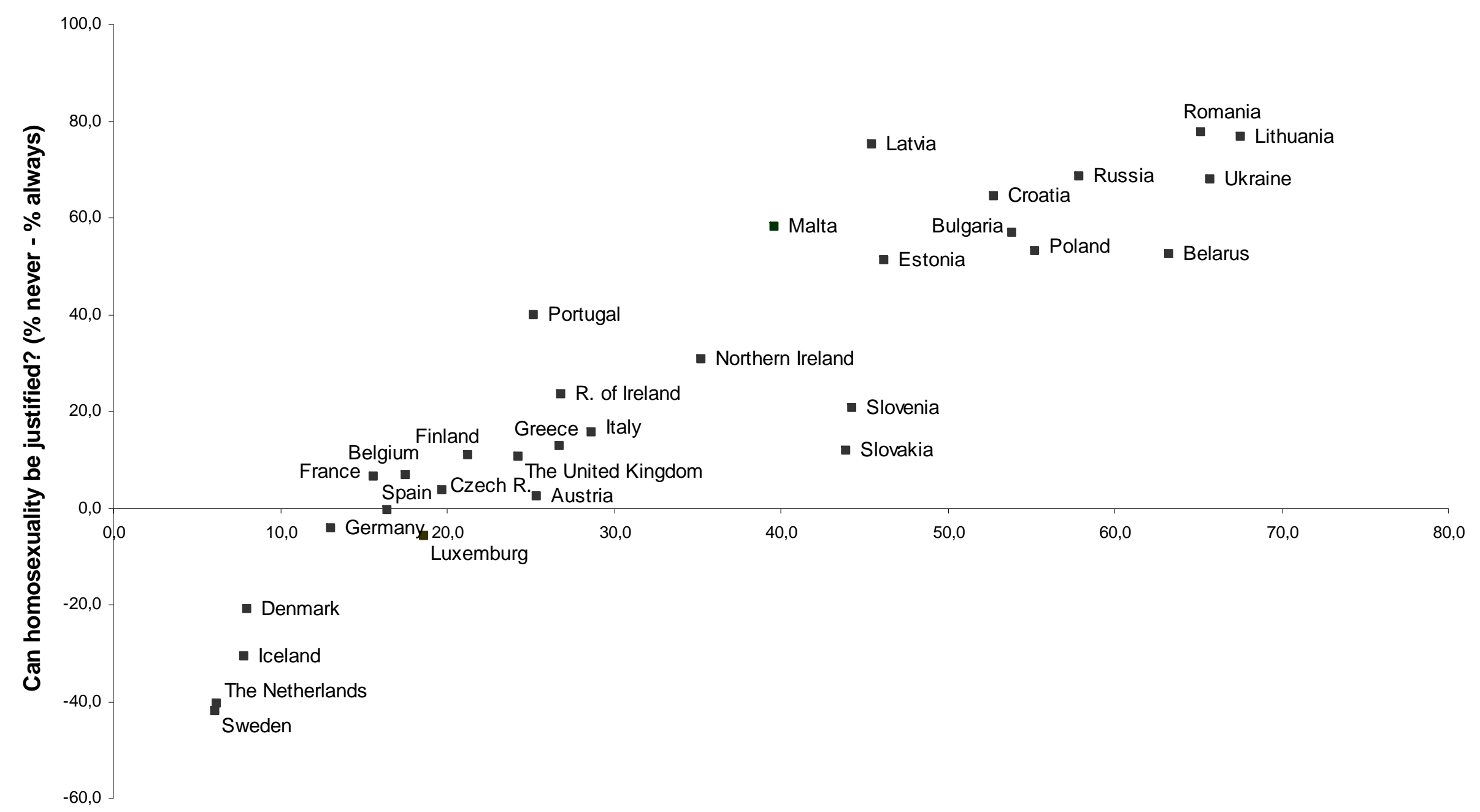

Would not like to have homosexual neighbor 